\title{
2. ALKENONE UNSATURATION ESTIMATES OF LATE MIOCENE THROUGH LATE PLIOCENE SEA-SURFACE TEMPERATURES AT SITE $958^{1}$
}

\author{
Timothy D. Herbert ${ }^{2}$ and Jeffrey D. Schuffert ${ }^{2}$
}

\begin{abstract}
Samples of pelagic carbonates from Ocean Drilling Program Hole 958A were analyzed for the unsaturation index of $\mathrm{C}_{37}$ alkenones, a proxy for sea-surface temperature (SST), over a record that ranges from 2.2 to $6.5 \mathrm{Ma}$. Sufficient alkenones were recovered from all samples to estimate past SST. The profile shows quite stable unsaturation values from 6.5 to 2.5 Ma. Two significant excursions toward lower unsaturation indices occur at $\sim 2.3$ and $2.5 \mathrm{Ma}$, with a more modest decrease at $\sim 3.1 \mathrm{Ma}$. These indicate that North Atlantic SST decreased during times of increased Northern Hemisphere glaciation. Using the Prahl et al. (1988) calibration to convert unsaturation indices to paleotemperature, we deduce that late Miocene through early late Pliocene SSTs at the location of Hole 958A were about $25.3 \pm 1{ }^{\circ} \mathrm{C}$, and that the late Pliocene coolings associated with glaciation were of the order of $5^{\circ} \mathrm{C}$, similar in magnitude to the most recent glacial-interglacial change in SST in the region. Results from Site 958 suggest that, with the initiation of Northern Hemisphere ice sheets, high latitude temperature anomalies were linked to large decreases in ocean temperatures in the subtropical North Atlantic.
\end{abstract}

\section{INTRODUCTION}

For a little more than a decade, organic geochemists have been developing an understanding of the environmental significance of the unsaturation index of organic biomarkers $\left(\mathrm{C}_{37}\right.$ and $\mathrm{C}_{38}$ alkenones), compounds uniquely synthesized by a few species of haptophyte algae (Conte et al., 1992; Volkman et al., 1980; Marlowe et al., 1984; Brassell et al., 1986; Prahl et al., 1988; Brassell, 1993). Although early reports included mention of alkenones in samples as old as Eocene age (Marlowe et al., 1984), and subsequent studies found $\mathrm{C}_{40}$ ketones in sediments of Cretaceous age (Farrimond et al., 1986; Yamamoto et al., 1996), most studies have concentrated on alkenone determinations over the past few glacial cycles, the time range over which the two principal modern alkenone-synthesizing species, Emiliania huxleyi and Gephyrocapsa oceanica have both existed (Jasper and Gagosian, 1989; Eglinton et al., 1992; Lyle et al., 1992; Rostek et al., 1993; Zhao et al., 1993; Prahl et al., 1995; Schneider et al., 1995; Emeis et al., 1995). Calibration functions have been developed to relate the unsaturation index, which is defined as

$$
\mathrm{Uk}^{\mathrm{k}^{\prime}}{ }_{37}=\mathrm{C}_{37: 2} /\left(\mathrm{C}_{37: 2}+\mathrm{C}_{37: 3}\right)
$$

(Prahl et al., 1988) to the growth temperature. In most cases, field and laboratory culture studies have assumed that E. huxleyi is the dominant alkenone-producing species in the modern ocean.

We report here on the results of $\mathrm{U}^{\mathrm{k}^{\prime}}{ }_{37}$ time series applied to sediments that significantly predate the evolutionary appearance of $E$. huxleyi at about $0.26 \mathrm{Ma}$. Pliocene through late Miocene-age samples were obtained from ODP Hole 958A at a rate of two per section from Cores $159-958 \mathrm{~A}-5 \mathrm{H}$ through $14 \mathrm{H}$. Age assignment of the samples was derived from a smoothed-spline fit of biostratigraphic age estimates (Firth et al., 1996) as a function of depth (Fig. 1). The sampling resolution is $\sim 60 \mathrm{k} . \mathrm{y}$. for the time interval $2.2-4 \mathrm{Ma}$, and $\sim 25 \mathrm{k} . \mathrm{y}$. for the interval from 4 to $6.5 \mathrm{Ma}$. It is important to note that this sampling is below the resolution required to detect obliquity- (41-k.y. period)

${ }^{1}$ Firth, J.V. (Ed.), 1998. Proc. ODP, Sci. Results, 159T: College Station, TX (Ocean Drilling Program).

${ }^{2}$ Department of Geological Sciences, Box 1846, Brown University, Providence, RI 02912 U.S.A. timothy_herbert@brown.edu

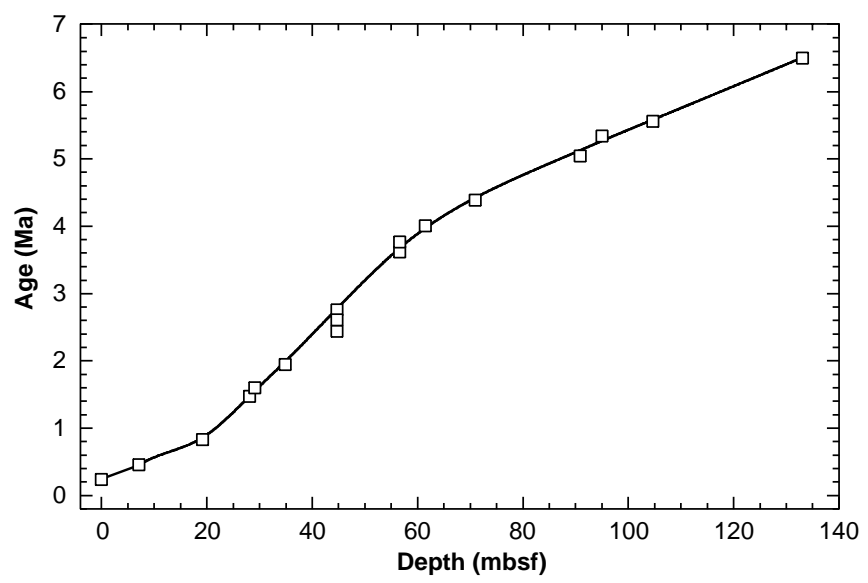

Figure 1. Model used to convert samples obtained from Hole 958A to age, via a smooth spline fit (solid curve). The age estimates are taken from biostratigraphic data listed in Firth et al. (1996).

and precessional- (23- and 19-k.y. periods) related climatic cycles and at about the limit for resolving 100-k.y. cycles related to eccentricity. Orbital-scale variance is evident in core photographs of Site 958 sediments, which show alternating lithologies on decimeter scales (see Firth et al., 1996). Orbital-climatic sensitivity in Pliocene and late Miocene time periods has already been demonstrated by analyses of oxygen isotopes (Raymo et al., 1992; Shackleton et al., 1995) and lithologic time series (Bloemendal and deMenocal, 1989; deMenocal, 1995). We thus consider our results to provide an indication of the variance of sea-surface temperature (SST) from 2.2 to 6.5 $\mathrm{Ma}$ in the subtropical North Atlantic that will need development through high-resolution sampling.

\section{METHODS}

Samples ( $\sim 6$ g dry weight) were freeze-dried and extracted in a $3: 1(\mathrm{v} / \mathrm{v})$ methanol:hexane solution using an automated pressurized fluid extraction (PFE) device (ASE 200). This instrument exposes 
samples to small volumes of solvent at elevated pressure and temperature. It extracts organic compounds rapidly and delivers the extracts to annealed glass vials with PTFE septa. Extractions were carried out for 15 -min at $150^{\circ} \mathrm{C}$. Cross-checks with homogenized material show no difference in recovery efficiency or in unsaturation index between Soxhlet and PFE methods. Organic extracts were dried under a nitrogen stream prior to dilution for gas chromatography. All samples were analyzed for alkenones by gas chromatography with flame-ionization detection. Samples were prepared using toluene as a solvent, and autosampler vials were sealed with PTFE septa to prevent the appearance of ghost peaks observed with rubber or silicone septa. The chromatographic column used was an HP-1 (50-m length, 0.2-mm diameter and $0.11-\mu \mathrm{m}$ film thickness). Temperature programming was $12.5^{\circ} \mathrm{C} / \mathrm{min}$ to $250^{\circ} \mathrm{C}$, followed by $1^{\circ} \mathrm{C} / \mathrm{min}$ to $290^{\circ} \mathrm{C}$, with an isothermal holding step at $320^{\circ} \mathrm{C}$ for $15 \mathrm{~min}$. Calculation of the $\mathrm{U}^{\mathrm{k}^{\prime}}{ }_{37}$ index followed graphical determination of $\mathrm{C}_{37: 3}$ and $\mathrm{C}_{37: 2}$ peak areas using Hewlett-Packard Chemstation software. Quantification of abundance is achieved by addition of $\mathrm{C}_{36}$ and $\mathrm{C}_{37} n$-alkanes as external standards.

We routinely achieved a reproducibility of $\pm 0.01 \mathrm{U}^{\mathrm{k}^{\prime}}{ }_{37}$ units, as determined by multiple extractions of sediment standards from the Santa Barbara Basin and the central California Margin. This corresponds to a nominal $0.3^{\circ} \mathrm{C}$ temperature uncertainty using the Prahl et al. (1988) calibration and barring other complications in interpreting the unsaturation index. Several modifications of laboratory procedures helped us to avoid steps in sample preparation that can lead to small (order of 0.02-0.04 $\mathrm{U}^{\mathrm{k}^{\prime}}{ }_{37}$ units) but systematic biases in the final $\mathrm{U}^{\mathrm{k}^{\prime}}{ }_{37}$ determination. We found that using hexane to transfer lipid extracts can cause a noticeable fractionation in favor of the $\mathrm{C}_{37: 3}$ alkenone; this was verified by a number of replicate leaches of the walls of glassware using methylene chloride following transfer with hexane. Small amounts of alkenones, but with a highly pronounced $\mathrm{C}_{37: 2}$ to $\mathrm{C}_{37: 3}$ ratio were detected in these residues by gas chromatography. No residual alkenones were detected in glassware if methylene chloride or methanol was used to transfer lipid extracts.

No silical-gel column clean-up procedure was used because this often leads to fractionation of the $\mathrm{Uk}^{\prime}{ }_{37}$ index (Rossell-Mele, 1994; Zhao, pers. comm. 1996; Herbert, unpubl. data). We also ran samples within 2-3 days after extraction to minimize a time-dependent reduction in $\mathrm{C}_{37}$ ketone abundance (oxidation?) that can bias the $\mathrm{U}^{\mathrm{k}^{\prime}}{ }_{37}$ ratio.

\section{RESULTS}

All 133 samples extracted yielded sufficient alkenones for $\mathrm{U}^{\mathrm{k}^{\prime}}{ }_{37}$ determination (Table 1). Sample chromatograms are presented in Figure 2. Abundances varied from 7 to $1750 \mathrm{ng} / \mathrm{g}$ dry sediment, with an average of $\sim 120 \mathrm{ng} / \mathrm{g}$. Similar values are recorded in late Pleistocene-age pelagic sediments (Prahl et al., 1989; Sikes et al., 1991); Holocene-age continental margin sediments from upwelling areas contain one to three orders of magnitude higher concentrations of $\mathrm{C}_{37}$ alkenones (McCaffrey et al., 1990; Kennedy and Brassell, 1992). Organic geochemical analyses from Ocean Drilling Program (ODP) Site 958 thus help to confirm the diagenetic longevity of alkenones inferred from storage experiments (Sikes et al., 1991) and from other reports of their occurrence in pre-Pleistocene sediments (Marlowe, 1984; Brassell, 1993; van der Smissen and Rulkotter, 1996).

The $\mathrm{U}^{\mathrm{k}^{\prime}}{ }_{37}$ time series is displayed in Figure 3. Age assignments of individual samples have uncertainties on the order of 0.1 m.y., and the effect of uneven temporal sampling is evident in the higher concentration of data in the older portion of the record. The average $\mathrm{U}^{\mathrm{k}^{\prime}}{ }_{37}$ value for the entire data set is 0.901 , which, using the Prahl et al. (1988) calibration, corresponds to an average SST at Site 958 of $25.3^{\circ} \mathrm{C}$ for the time period 2.2-6.5 Ma. We also show in Figure 3 a benthic isotope curve over the same time interval from Shackleton et al. (1995), which provides a reference curve for global climate. Note that the correlations indicated by dashed lines are tentative, and that the time scale for the Shackleton et al. (1995) isotope data is considerably more precise than that for Hole 958A.

$\mathrm{U}^{\mathrm{k}^{\prime}}{ }_{37}$ data at Hole 958A show a significant relation to late Miocene to late Pliocene climatic history. The record prior to about 3.5 Ma has small (order of $1^{\circ} \mathrm{C}$ reconstructed SST) variances with suggestions of long wavelength (order of 0.5 m.y.) trends in unsaturation and SST. Beginning at $\sim 3.5 \mathrm{Ma}$, and becoming more intense at $\sim 2.5 \mathrm{Ma}$, large $\mathrm{U}^{\prime}{ }_{37}$ anomalies appear. These take the form of sharp decreases in SST on the order of $5^{\circ} \mathrm{C}$. In each case, the "cold" anomalies coincide with carbonate-poor beds documented in core photographs (Firth et al., 1996). Cold SST anomalies at Site 958, as inferred from alkenone measurements, coincide to within stratigraphic error with the by now well-established onset of large-scale Northern Hemisphere glaciation between 2.5 and $3 \mathrm{Ma}$ (Shackleton et al., 1984; Raymo, 1994). The organic geochemical data argue that the climatic coolings associated with the appearance of ice-rafted debris in the North Atlantic and with increased oxygen isotopic variance led to substantial reductions in subtropical SST as well. Cooling of surface waters apparently accompanied low-carbonate intervals in the sediment, the same association of lithology that characterizes late Pleistocene carbonate cycles of the North Atlantic (Gardner, 1975).

\section{CALIBRATION OF $\mathbf{U}^{\mathbf{k}^{\prime}}{ }_{37}$ TO SST}

How faithfully do the $\mathrm{U}^{\mathrm{k}^{\prime}}{ }_{37}$ values from Pliocene and late Miocene samples record past SST? Throughout this paper, we have converted unsaturation indices to estimated SST using the Prahl et al. (1988) calibration. There are good reasons to believe that the interpretation of relative changes in surface ocean temperature is secure. First, the basic relation of alkenone unsaturation index to growth temperature seems to be a robust biological response (Prahl and Wakeham, 1987; Prahl et al., 1988; Brassell, 1993; Lesley et al., 1996). The co-occurrence of alkenones and nannofossils of the family Gephyrocapsae since the Eocene (Marlowe et al., 1990) suggests that alkenone synthesis originated in haptophytes ancestral to modern-day alkenoneproducing species. As long as the alkenones performed a similar biological function (membrane related? see Prahl et al., 1988), it is reasonable to assume that calibration functions developed from modern species should apply to the older record. The precise calibration of $\mathrm{U}^{\mathrm{k}^{\prime}}{ }_{37}$ to SST must, of course, remain more uncertain, as the relation demonstrated by field and laboratory studies dominated by $E$. huxleyi may not be strictly applicable to older sediments. Again, we feel that the reconstruction presented in Figure 3 is probably close to the truth. There is no evidence, for example, that late Pleistocene $\mathrm{U}^{\mathrm{k}^{\prime}}{ }_{37}$ time series show breaks in the mean or variance at $0.26 \mathrm{Ma}$, the first evolutionary appearance of E. huxleyi (Brassell et al., 1986; Emeis et al., 1995). Furthermore, although it has been suggested that G. oceanica, and by extension other precursor alkenone-synthesizing species, may have different relations of alkenone unsaturation index to growth temperature (Volkman et al., 1995), core-top studies fail to find evidence for significant departures from a global relation of unsaturation to SST (Sikes et al., 1991; Brassell, 1993; Rossell-Mele et al., 1994; Sonzogni et al., 1997) even where a major fraction of the coccolithophorid flora is composed of G. oceanica (Herbert et al., in press). We also note that the relationship of $\mathrm{U}^{\mathrm{k}^{\prime}}{ }_{37}$ to the equivalent unsaturation index of the $\mathrm{C}_{38}$ methyl ketones, $\mathrm{U}^{\mathrm{k}^{\prime}}{ }_{38 \mathrm{me}}$, for Pliocene and Miocene age samples is identical to that established for late Pleistocene material. This observation argues that the systematics of the alkenone unsaturation response have remained similar over long time spans.

Finally, the association of large $\mathrm{U}^{\mathrm{k}^{\prime}}{ }_{37}$ anomalies at Site 958 with a global climatic transition well documented at other sites by other sediment proxies (Shackleton et al., 1984; Shackleton et al., 1995; Raymo, 1994) is unlikely to be coincidental. The consistent association of cool reconstructed SST with independent lithologic indices of pa- 
Table 1: Alkenone results from Hole 958A.

\begin{tabular}{|c|c|c|c|c|c|}
\hline $\begin{array}{l}\text { Core, section, } \\
\text { interval }(\mathrm{cm})\end{array}$ & $\begin{array}{l}\text { Depth } \\
\text { (mbsf) }\end{array}$ & $\begin{array}{l}\text { Age } \\
(\mathrm{Ma})\end{array}$ & $\mathrm{U}^{\mathrm{k}^{\prime}}{ }_{37}$ & $\begin{array}{l}\text { SST } \\
\left({ }^{\circ} \mathrm{C}\right)\end{array}$ & $\begin{array}{c}\mathrm{C}_{37} \text { Conc. } \\
\text { (ng/g) }\end{array}$ \\
\hline $5 \mathrm{H}-1,45-50$ & 38.475 & 2.21 & 0.780 & 21.8 & 877 \\
\hline $5 \mathrm{H}-1,125-130$ & 39.128 & 2.25 & 0.867 & 24.3 & 293 \\
\hline $5 \mathrm{H}-2,45-50$ & 39.975 & 2.32 & 0.897 & 25.2 & 88 \\
\hline $5 \mathrm{H}-2,125-130$ & 40.775 & 2.37 & 0.868 & 24.4 & 319 \\
\hline $5 \mathrm{H}-3,45-50$ & 41.475 & 2.42 & 0.804 & 22.6 & 460 \\
\hline $5 \mathrm{H}-3,125-130$ & 42.128 & 2.47 & 0.735 & 20.5 & 852 \\
\hline $5 \mathrm{H}-4,45-50$ & 42.975 & 2.54 & 0.866 & 24.3 & 236 \\
\hline $5 \mathrm{H}-4,125-130$ & 43.775 & 2.60 & 0.920 & 25.9 & 243 \\
\hline $5 \mathrm{H}-5,45-50$ & 44.475 & 2.65 & 0.877 & 24.6 & 223 \\
\hline $5 \mathrm{H}-5,125-130$ & 45.128 & 2.71 & 0.901 & 25.3 & 189 \\
\hline $5 \mathrm{H}-6,45-50$ & 45.975 & 2.77 & 0.895 & 25.2 & 288 \\
\hline $5 \mathrm{H}-6,125-130$ & 46.775 & 2.84 & 0.896 & 25.2 & 209 \\
\hline $6 \mathrm{H}-1,45-50$ & 47.975 & 2.94 & 0.866 & 24.3 & 259 \\
\hline $6 \mathrm{H}-1,125-130$ & 48.775 & 3.01 & 0.863 & 24.2 & 364 \\
\hline $6 \mathrm{H}-2,45-50$ & 49.475 & 3.07 & 0.824 & 23.1 & 1749 \\
\hline $6 \mathrm{H}-2,125-130$ & 50.275 & 3.13 & 0.874 & 24.6 & 598 \\
\hline $6 \mathrm{H}-3,45-50$ & 50.975 & 3.19 & 0.895 & 25.2 & 170 \\
\hline $6 \mathrm{H}-3,125-130$ & 51.775 & 3.26 & 0.906 & 25.5 & 109 \\
\hline $6 \mathrm{H}-4,45-50$ & 52.475 & 3.32 & 0.887 & 24.9 & 197 \\
\hline $6 \mathrm{H}-4,125-130$ & 53.275 & 3.38 & 0.903 & 25.4 & 148 \\
\hline $6 \mathrm{H}-5,45-50$ & 53.975 & 3.44 & 0.924 & 26.1 & 93 \\
\hline $6 \mathrm{H}-5,125-130$ & 54.775 & 3.50 & 0.875 & 24.6 & 215 \\
\hline $6 \mathrm{H}-6,45-50$ & 55.475 & 3.56 & 0.896 & 25.2 & 122 \\
\hline $6 \mathrm{H}-6,125-130$ & 56.275 & 3.62 & 0.917 & 25.8 & 172 \\
\hline $7 \mathrm{H}-1,45-50$ & 57.457 & 3.71 & 0.913 & 25.7 & 141 \\
\hline $7 \mathrm{H}-1,125-130$ & 58.275 & 3.76 & 0.928 & 26.2 & 126 \\
\hline $7 \mathrm{H}-2,45-50$ & 58.975 & 3.81 & 0.907 & 25.5 & 221 \\
\hline $7 \mathrm{H}-2,125-130$ & 59.775 & 3.86 & 0.896 & 25.2 & 80 \\
\hline $7 \mathrm{H}-3,45-50$ & 60.457 & 3.91 & 0.903 & 25.4 & 165 \\
\hline $7 \mathrm{H}-3,125-130$ & 61.275 & 3.96 & 0.896 & 25.2 & 296 \\
\hline $7 \mathrm{H}-4,45-50$ & 61.975 & 4.00 & 0.925 & 26.2 & 103 \\
\hline $7 \mathrm{H}-4,125-130$ & 62.775 & 4.04 & 0.926 & 26.1 & 98 \\
\hline $7 \mathrm{H}-5,45-50$ & 63.457 & 4.08 & 0.926 & 26.1 & 102 \\
\hline $7 \mathrm{H}-5,125-130$ & 64.275 & 4.12 & 0.958 & 27.2 & 76 \\
\hline $7 \mathrm{H}-6,45-50$ & 64.975 & 4.16 & 0.951 & 26.8 & 38 \\
\hline $7 \mathrm{H}-6,119-124$ & 65.720 & 4.20 & 0.948 & 26.7 & 86 \\
\hline $8 \mathrm{H}-1,45-50$ & 66.975 & 4.25 & 0.920 & 25.9 & 104 \\
\hline $8 \mathrm{H}-1,125-130$ & 67.775 & 4.29 & 0.943 & 26.6 & 111 \\
\hline $8 \mathrm{H}-2,45-50$ & 68.475 & 4.32 & 0.937 & 26.5 & 62 \\
\hline $8 \mathrm{H}-2,125-130$ & 69.275 & 4.36 & 0.914 & 25.7 & 129 \\
\hline $8 \mathrm{H}-3,45-50$ & 69.975 & 4.39 & 0.895 & 25.2 & 38 \\
\hline $8 \mathrm{H}-3,125-130$ & 70.775 & 4.42 & 0.916 & 25.8 & 67 \\
\hline $8 \mathrm{H}-4,45-50$ & 71.475 & 4.45 & 0.898 & 25.3 & 93 \\
\hline $8 \mathrm{H}-4,125-130$ & 72.275 & 4.48 & 0.903 & 25.4 & 52 \\
\hline $8 \mathrm{H}-5,45-50$ & 72.975 & 4.51 & 0.905 & 25.5 & 93 \\
\hline $8 \mathrm{H}-5,125-130$ & 73.775 & 4.54 & 0.918 & 25.8 & 180 \\
\hline $8 \mathrm{H}-6,45-50$ & 74.475 & 4.56 & 0.898 & 25.3 & 76 \\
\hline $8 \mathrm{H}-6,125-130$ & 75.275 & 4.59 & 0.920 & 25.9 & 141 \\
\hline $9 \mathrm{H}-1,45-50$ & 76.475 & 4.64 & 0.898 & 25.3 & 90 \\
\hline $9 \mathrm{H}-1,125-130$ & 77.275 & 4.67 & 0.929 & 26.2 & 62 \\
\hline $9 \mathrm{H}-2,45-50$ & 77.975 & 4.69 & 0.891 & 25.1 & 214 \\
\hline $9 \mathrm{H}-2,125-130$ & 78.775 & 4.72 & 0.922 & 26.0 & 329 \\
\hline $9 \mathrm{H}-3,45-50$ & 79.475 & 4.74 & 0.911 & 25.7 & 80 \\
\hline $9 \mathrm{H}-3,125-130$ & 80.275 & 4.77 & 0.896 & 25.2 & 56 \\
\hline $9 \mathrm{H}-4,45-50$ & 80.975 & 4.79 & 0.910 & 25.6 & 70 \\
\hline $9 \mathrm{H}-4,125-130$ & 81.775 & 4.82 & 0.864 & 24.3 & 202 \\
\hline $9 \mathrm{H}-5,45-50$ & 82.475 & 4.84 & 0.920 & 25.9 & 39 \\
\hline $9 \mathrm{H}-5,125-130$ & 83.275 & 4.87 & 0.849 & 23.8 & 239 \\
\hline $9 \mathrm{H}-6,45-50$ & 83.975 & 4.89 & 0.908 & 25.5 & 115 \\
\hline $9 \mathrm{H}-6,125-130$ & 84.775 & 4.92 & 0.908 & 25.5 & 76 \\
\hline $10 \mathrm{H}-1,45-50$ & 85.975 & 4.96 & 0.899 & 25.3 & 103 \\
\hline
\end{tabular}

\begin{tabular}{|c|c|c|c|c|c|}
\hline $\begin{array}{l}\text { Core, section, } \\
\text { interval }(\mathrm{cm})\end{array}$ & $\begin{array}{l}\text { Depth } \\
\text { (mbsf) }\end{array}$ & $\begin{array}{l}\text { Age } \\
\text { (Ma) }\end{array}$ & $\mathrm{U}^{\mathrm{k}^{\prime}}{ }_{37}$ & $\begin{array}{l}\text { SST } \\
\left({ }^{\circ} \mathrm{C}\right)\end{array}$ & $\begin{array}{c}\mathrm{C}_{37} \text { Conc. } \\
\text { (ng/g) }\end{array}$ \\
\hline $10 \mathrm{H}-1,125-130$ & 86.775 & 4.99 & 0.938 & 26.4 & 39 \\
\hline $10 \mathrm{H}-2,45-50$ & 87.475 & 5.01 & 0.908 & 25.5 & 17 \\
\hline $10 \mathrm{H}-2,125-130$ & 88.275 & 5.03 & 0.949 & 26.7 & 73 \\
\hline $10 \mathrm{H}-3,45-50$ & 88.975 & 5.06 & 0.937 & 26.4 & 54 \\
\hline $10 \mathrm{H}-3,125-130$ & 89.775 & 5.08 & 0.893 & 25.1 & 70 \\
\hline $10 \mathrm{H}-4,45-50$ & 90.475 & 5.11 & 0.900 & 25.3 & 43 \\
\hline $10 \mathrm{H}-4,125-130$ & 91.275 & 5.13 & 0.904 & 25.4 & 9 \\
\hline $10 \mathrm{H}-5,45-50$ & 91.975 & 5.16 & 0.893 & 25.1 & 10 \\
\hline $10 \mathrm{H}-5,125-130$ & 92.775 & 5.19 & 0.936 & 26.4 & 16 \\
\hline $10 \mathrm{H}-6,45-50$ & 93.475 & 5.21 & 0.917 & 25.8 & 33 \\
\hline $10 \mathrm{H}-6,125-130$ & 94.275 & 5.24 & 0.937 & 26.4 & 17 \\
\hline $11 \mathrm{H}-1,45-50$ & 95.475 & 5.28 & 0.923 & 26.0 & 14 \\
\hline $11 \mathrm{H}-1,125-130$ & 96.275 & 5.30 & 0.919 & 25.9 & 16 \\
\hline $11 \mathrm{H}-2,45-50$ & 96.975 & 5.33 & 0.907 & 25.5 & 27 \\
\hline $11 \mathrm{H}-2,125-130$ & 97.775 & 5.35 & 0.944 & 26.6 & 47 \\
\hline $11 \mathrm{H}-3,45-50$ & 98.475 & 5.38 & 0.931 & 26.2 & 34 \\
\hline $11 \mathrm{H}-3,125-130$ & 99.275 & 5.40 & 0.903 & 25.4 & 119 \\
\hline $11 \mathrm{H}-4,45-50$ & 99.975 & 5.42 & 0.902 & 25.4 & 99 \\
\hline $11 \mathrm{H}-4,125-130$ & 100.775 & 5.45 & 0.908 & 25.6 & 101 \\
\hline $11 \mathrm{H}-5,45-50$ & 101.475 & 5.47 & 0.908 & 25.6 & 69 \\
\hline $11 \mathrm{H}-5,125-130$ & 102.275 & 5.50 & 0.894 & 25.1 & 55 \\
\hline $11 \mathrm{H}-6,45-50$ & 102.975 & 5.52 & 0.892 & 25.1 & 41 \\
\hline $11 \mathrm{H}-7,41-46$ & 104.43 & 5.57 & 0.903 & 25.4 & 72 \\
\hline $12 \mathrm{H}-1,45-50$ & 104.975 & 5.59 & 0.904 & 25.4 & 91 \\
\hline $12 \mathrm{H}-1,125-130$ & 105.775 & 5.61 & 0.904 & 25.4 & 39 \\
\hline $12 \mathrm{H}-2,45-50$ & 106.475 & 5.63 & 0.893 & 25.1 & 27 \\
\hline $12 \mathrm{H}-2,125-130$ & 107.275 & 5.66 & 0.881 & 24.8 & 43 \\
\hline $12 \mathrm{H}-3,45-50$ & 107.975 & 5.68 & 0.872 & 24.5 & 25 \\
\hline $12 \mathrm{H}-3,125-130$ & 108.775 & 5.71 & 0.873 & 24.5 & 18 \\
\hline $12 \mathrm{H}-4,45-50$ & 109.475 & 5.73 & 0.894 & 25.1 & 30 \\
\hline $12 \mathrm{H}-4,125-130$ & 110.275 & 5.76 & 0.872 & 24.5 & 22 \\
\hline $12 \mathrm{H}-5,45-50$ & 110.975 & 5.78 & 0.913 & 25.7 & 96 \\
\hline $12 \mathrm{H}-5,125-130$ & 111.775 & 5.81 & 0.903 & 25.4 & 27 \\
\hline $12 \mathrm{H}-6,45-50$ & 112.475 & 5.83 & 0.904 & 25.5 & 64 \\
\hline $12 \mathrm{H}-6,125-130$ & 113.275 & 5.85 & 0.900 & 25.3 & 33 \\
\hline $13 \mathrm{H}-1,45-50$ & 114.475 & 5.89 & 0.906 & 25.5 & 40 \\
\hline $13 \mathrm{H}-1,125-130$ & 115.275 & 5.92 & 0.928 & 26.1 & 37 \\
\hline $13 \mathrm{H}-2,45-50$ & 115.975 & 5.94 & 0.889 & 25.0 & 37 \\
\hline $13 \mathrm{H}-2,125-130$ & 116.775 & 5.97 & 0.933 & 26.3 & 37 \\
\hline $13 \mathrm{H}-3,45-50$ & 117.475 & 5.99 & 0.914 & 25.7 & 36 \\
\hline $13 \mathrm{H}-3,125-130$ & 118.275 & 6.02 & 0.898 & 25.3 & 44 \\
\hline $13 \mathrm{H}-4,45-50$ & 118.975 & 6.04 & 0.923 & 26.0 & 19 \\
\hline $13 \mathrm{H}-4,125-130$ & 119.775 & 6.07 & 0.904 & 25.5 & 12 \\
\hline $13 \mathrm{H}-5,45-50$ & 120.475 & 6.09 & 0.895 & 25.2 & 14 \\
\hline $13 \mathrm{H}-5,125-130$ & 121.275 & 6.11 & 0.911 & 25.6 & 9 \\
\hline $13 \mathrm{H}-6,45-50$ & 121.975 & 6.14 & 0.892 & 25.1 & 16 \\
\hline $13 \mathrm{H}-6,125-130$ & 122.775 & 6.16 & 0.931 & 26.2 & 18 \\
\hline $13 \mathrm{H}-7,45-50$ & 123.475 & 6.19 & 0.952 & 26.9 & 33 \\
\hline $14 \mathrm{H}-1,45-50$ & 123.975 & 6.20 & 0.938 & 26.4 & 49 \\
\hline $14 \mathrm{H}-1,125-130$ & 124.775 & 6.23 & 0.908 & 25.6 & 18 \\
\hline $14 \mathrm{H}-2,45-50$ & 125.575 & 6.25 & 0.901 & 25.3 & 16 \\
\hline $14 \mathrm{H}-2,125-130$ & 126.275 & 6.28 & 0.913 & 25.7 & 16 \\
\hline $14 \mathrm{H}-3,45-50$ & 126.975 & 6.30 & 0.911 & 25.6 & 16 \\
\hline $14 \mathrm{H}-3,125-130$ & 127.775 & 6.33 & 0.902 & 25.4 & 13 \\
\hline $14 \mathrm{H}-4,45-50$ & 128.575 & 6.35 & 0.842 & 23.6 & 7 \\
\hline $14 \mathrm{H}-4,125-130$ & 129.275 & 6.38 & 0.875 & 24.6 & 13 \\
\hline $14 \mathrm{H}-5,45-50$ & 129.975 & 6.40 & 0.914 & 25.7 & 14 \\
\hline $14 \mathrm{H}-5,125-130$ & 130.775 & 6.42 & 0.852 & 23.9 & 10 \\
\hline $14 \mathrm{H}-6,45-50$ & 131.575 & 6.45 & 0.890 & 25.0 & 16 \\
\hline $14 \mathrm{H}-6,125-130$ & 132.275 & 6.47 & 0.863 & 24.2 & 10 \\
\hline
\end{tabular}

leoclimate (low carbonate intervals) in Site 958 core material argues for causal links between $\mathrm{U}^{\mathrm{k}^{\prime}}$ and climate. As is true for the late Pleistocene, glacial phases of climate produced low-carbonate sediments in the North Atlantic and lowered SST. We cannot exclude biases built into the alkenone recorder as a result of seasonal variations in haptophyte algal production and depth habitat (Conte et al., 1992; Prahl et al., 1993). It seems likely, however, that these would be small in comparison to the $\sim 5^{\circ} \mathrm{C}$ anomalies detected near the 2.5 -Ma climatic transition.

\section{SIGNIFICANCE OF THE HOLE 958A ALKENONE RECORD}

The temperature estimates provided by alkenone data suggest that increases in high-latitude Northern Hemisphere ice volume coincided with significant transient cooling in the subtropical North Atlantic. With better sample resolution, these reductions in SST will almost certainly correspond to the orbitally paced $\delta^{18} \mathrm{O}$ record (e.g., Raymo, 1994; Shackleton et al., 1995). The approximately $5^{\circ} \mathrm{C}$ lower SST deduced for some Pliocene glaciations is comparable to the most recent $4.5^{\circ} \mathrm{C}$ glacial-interglacial cooling determined from alkenone time series at ODP Site 658 (Zhao et al., 1993), located about $3^{\circ}$ south of ODP Site 958 , and to the $4^{\circ}-6^{\circ} \mathrm{C}$ cooling from the Holocene to the Last Glacial Maximum estimated from planktonic foraminifer transfer functions (CLIMAP, 1981; Mix et al., 1986).

The virtue of the organic geochemical determinations is that they provide a proxy that is almost certainly related directly to past SST during a time interval in which other paleotemperature indices are problematic. While oxygen isotopic time series of planktonic foraminifers may well have temperature significance, it is not possible at present to partition variance in Pliocene and Miocene records into ice 

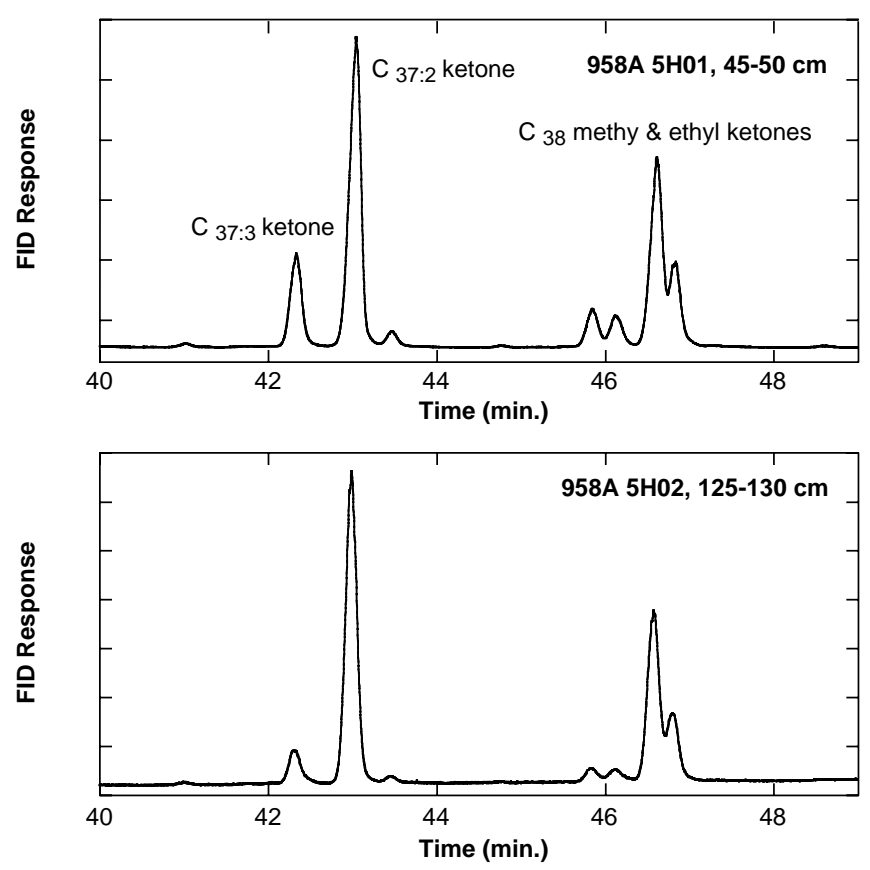

Figure 2. Representative gas chromatograms of "cold" and "warm" values for the alkenone unsaturation index obtained at Hole 958A. See Table 1 for depth and estimated age of samples.

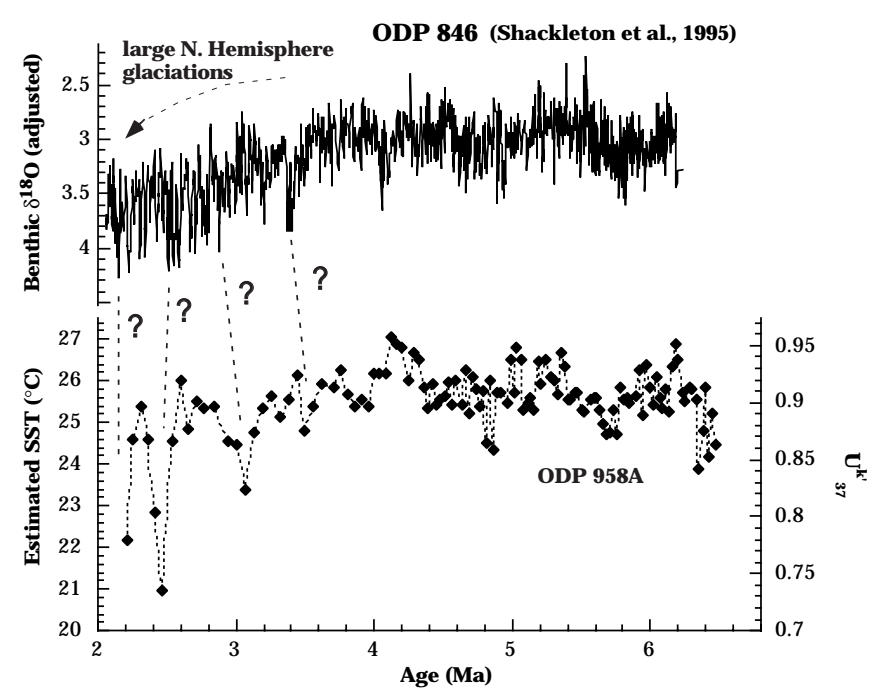

Figure 3. Time series of SST estimated from $\mathrm{U}^{\mathrm{k}^{\prime}}{ }_{37}$ values recorded at Hole 958A. Tentative correlation with global climatic events (benthic $\delta^{18} \mathrm{O}$ curve of Shackleton et al., 1995) suggested with dashed lines. Note the large increase in variance at $\sim 2.5 \mathrm{Ma}$, with possible cold "precursor" events at $\sim 3$ and 3.4 Ma. Cold anomalies are associated with clay-rich strata, and probably coincide with glacial events.

volume and temperature components with much certainty (Shackleton et al., 1995). Faunal assemblage data may also be used to map SST variations over this time (Dowsett and Poore, 1990; Dowsett et al., 1994), but because many assemblages in older sequences have no modern analogs, the calibration of micropaleontological data to temperature has large uncertainties. We argue that the unsaturation index of $\mathrm{C}_{37}$ alkenones has been demonstrated to have a fundamental rela- tionship to growth temperature in the modern environment, and that this general relationship should hold in the past.

Our results also shed light on the spectral transition seen in proxy records of African dust (Bloemendal and deMenocal, 1989; deMenocal, 1995) over the same time span. These authors have argued that the increase in 41-k.y. power found in tropical marine records of dust flux at $\sim 2.5$ Ma shows the penetration of high-latitude climatic influences into the tropical climate as Northern Hemisphere ice sheet sizes expanded. The $\mathrm{U}^{\mathrm{k}^{\prime}}{ }_{37}$ time series from Site 958 suggests that subtropical SSTs, which might be expected to have a strong effect on monsoonal climates of Africa, began to experience large amplitude changes at the same time. If glacial-interglacial SST variations in the Pliocene were similar in pattern to the Last Glacial Maximum (cf. CLIMAP, 1981), then changes even larger than the $5^{\circ} \mathrm{C}$ deduced for Hole 958A must have occurred in the North Atlantic.

A significant increase in the temporal resolution of alkenone unsaturation data is clearly needed for the time interval that spans the 2.5-Ma climatic transition, as is the addition of similar data at other locations from the North Atlantic. For example, the present data set does not resolve late Pliocene SST variations at the resolution of the orbital cycles that triggered changes in ice volume and other aspects of climate (cf. Raymo et al., 1992; Shackleton et al., 1995). One intriguing implication of our data is that a significant fraction of the planktonic (and perhaps benthic) foraminifer oxygen isotopic anomalies in the late Pliocene could be due to changes in ocean temperature rather than ice volume.

\section{ACKNOWLEDGMENTS}

We thank M. Zhao and an anonymous reviewer for constructive suggestions that improved this manuscript.

\section{REFERENCES}

Bloemendal, J., and deMenocal, P., 1989. Evidence for a change in the periodicity of tropical climate cycles at $2.4 \mathrm{Myr}$ from whole-core magnetic susceptibility measurements. Nature, 342:897-900.

Brassell, S.C., 1993. Applications of biomarkers for delineating marine paleoclimatic fluctuations during the Pleistocene. In Engel, M.H., and Macko, S.A. (Eds.), Organic Geochemistry: Principles and Applications: New York (Plenum), 699-738.

Brassell, S.C., Eglinton, G., Marlowe, I.T., Pflaumann, U., and Sarnthein, M., 1986. Molecular stratigraphy: a new tool for climatic assessment. Nature, 320:129-133.

CLIMAP Project Members, 1981. Seasonal reconstructions of the Earth's surface at the last glacial maximum. Geol. Soc. Am., Map and Chart Ser., MC36.

Conte, M.H., Eglinton, G., and Madureira, L.A.S., 1992. Long-chain alkenones and alkyl alkenoates as palaeotemperature indicators: their production, flux and early sedimentary diagenesis in the eastern North Atlantic. Org. Geochem., 19:287-298.

deMenocal, P.B., 1995. Plio-Pleistocene African climate. Science, 270:5359.

Dowsett, H.J., and Poore, R.Z., 1990. A new planktic foraminifer transfer function for estimating Pliocene-Holocene paleoceanographic conditions in the North Atlantic. Mar. Micropaleontol., 16:1-23.

Dowsett, H., Thompson, R., Barron, J., Cronin, T., Fleming, F., Ishman, S., Poore, R., Willard, D., and Holtz, T., Jr., 1994. Joint investigations of the Middle Pliocene climate I: PRISM paleoenvironmental reconstructions. Global Planet. Change, 9:169-195.

Eglinton, G., Bradshaw, S.A., Rossell, A., Sarnthein, M., Pflaumann, U., and Tiedemann, R., 1992. Molecular record of secular sea surface temperature changes on 100-year timescales for glacial terminations I, II, and IV. Nature, 356:423-426.

Emeis, K.-C., Anderson, D.M., Doose, H., Kroon, D., and Schulz-Bull, D., 1995. Sea-surface temperatures and the history of monsoon upwelling in the northwest Arabian Sea during the last 500,000 years. Quat. Res., 43:355-361. 
Emeis, K.-C., Doose, H., Mix, A., and Schulz-Bull, D., 1995. Alkenone seasurface temperatures and carbon burial at Site 846 (Eastern Equatorial Pacific Ocean): the last 1.3 m.y. In Pisias, N.G., Mayer, L.A., Janecek, T.R., Palmer-Julson, A., and van Andel, T.H. (Eds.), Proc. ODP, Sci. Results, 138: College Station, TX (Ocean Drilling Program), 605-613.

Farrimond, P., Eglinton, G., and Brassell, S.C., 1986. Alkenones in Cretaceous black shales, Blake-Bahama Basin, western North Atlantic. In Leythaeuser, D., and Rullkötter, J. (Eds.), Advances in Organic Geochemistry, 1985. Org. Geochem., 10:897-903.

Firth, J.V., Blum, P., Lindblom, S., Michels, K., Sager, W.W., and Winkler, A., 1996. Site 958. In Firth, J.V., et al., Proc. ODP, Init. Repts., 159T: College Station, TX (Ocean Drilling Program), 3-13.

Gardner, J.V., 1975. Late Pleistocene carbonate dissolution cycles in the eastern equatorial Atlantic. In Sliter, W.V., Bé, A.W.H., and Berger, W.H. (Eds.), Dissolution of Deep-Sea Carbonates. Spec. Publ. Cushman Found. Foraminiferal Res., 13:129-141.

Herbert, T.D., Schuffert, J.D., Thomas, D., Lange, K., Weinheimer, A., and Herguera, J.-C., in press. Depth and seasonality of alkenone production along the California margin inferred from a core-top transect. Paleoceanography.

Jasper, J., and Gagosian, R.B., 1989. Alkenone molecular stratigraphy in an oceanic environment affected by glacial freshwater events. Paleoceanography, 4:603-614.

Kennedy, J., and Brassell, S.C., 1992. Molecular records of twentieth century El Nino events in laminated sediments from Santa Barbara Basin. Nature, 357:62-64.

Lesley, D., Conte, M.H., Thompson, A., Harris, R.P., and Eglinton, G., 1996. Calibration of the alkenone/alkenoate temperature signal in selected $E$. huxleyi and Gephyrocapsa oceanica strains from different oceanic regions. Eos, 76:149.

Lyle, M., Prahl, F.G., and Sparrow, M.A., 1992. Upwelling and productivity changes inferred from a temperature record in the central equatorial Pacific. Nature, 355:812-815.

McCaffrey, M.A., Farrington, J.W., and Repeta, D.J., 1990. The organic geochemistry of Peru margin surface sediments: A comparison of the $\mathrm{C}_{37}$ alkenone and historical El Nino records. Geochim. Cosmochim. Acta, 54:1671-1682.

Marlowe, I.T., Brassell, S.C., Eglinton, G., and Green, J.C., 1984. Longchain unsaturated ketones and esters in living algae and marine sediments. Org. Geochem., 6:135-141.

— 1990. Long-chain alkenones and alkyl alkenoates and the fossil coccolith record of marine sediments. Chem. Geol., 88:349-375.

Mix, A.C., Ruddiman, W.F., and McIntyre, A., 1986. The late Quaternary paleoceanography of the tropical Atlantic. 1: Spatial variability of annual mean sea-surface temperatures, 0-20,000 years B.P. Paleoceanography, $1: 43-66$.

Prahl, F.G., Collier, R.B., Dymond, J., Lyle, M., and Sparrow, M.A., 1993. A biomarker perspective on prymnesiophyte productivity in the northeast Pacific Ocean. Deep-Sea Res. Part A, 40:2061-2076.

Prahl, F.G., Muehlhausen, L.A., and Lyle, M., 1989. An organic geochemical assessment of oceanographic conditions at MANOP Site C over the past 26,000 years. Paleoceanography, 4:495-510.

Prahl, F.G., Muehlhausen, L.A., and Zahnle, D.L., 1988. Further evaluation of long-chain alkenones as indicators of paleoceanographic conditions. Geochim. Cosmochim. Acta, 52:2303-2310.

Prahl, F.G., Pisias, N., Sparrow, M.A., and Sabin, A., 1995. Assessment of sea-surface temperature at $42^{\circ} \mathrm{N}$ in the California Current over the last 30,000 years. Paleoceanography, 10:763-773.

Prahl, F.G., and Wakeham, S.G., 1987. Calibration of unsaturation patterns in long-chain ketone compositions for paleotemperature assessment. Nature, 330:367-369.
Raymo, M.E., 1994. The initiation of Northern Hemisphere glaciation. Annu. Rev. Earth Planet. Sci., 22:353-383.

Raymo, M.E., Hodell, D., and Jansen, E., 1992. Response of deep ocean circulation to initiation of Northern Hemisphere glaciation (3-2 Ma). Paleoceanography, 7:645-672.

Rossell-Mele, A., 1994. Long-chain Alkenone and alkyl alkenoate, and total pigment abundances as climatic proxy-indicators in the Northeastern Atlantic [Ph.D. thesis]. Univ. of Bristol.

Rossell-Mele, A., Carter, J., and Eglinton, G., 1994. Distribution of longchain alkenones and alkyl alkenoates in marine surface sediments from the North East Atlantic. Org. Geochem., 22:501-509.

Rostek, F., Ruhland, G., Bassinot, F.C., Muller, P.J., Labeyrie, L.D., Lancelot, Y., and Bard, E., 1993. Reconstructing sea surface temperature using $\delta^{18} \mathrm{O}$ and alkenone records. Nature, 364:319-321.

Schneider, R.R., Müller, P.J., and Ruhland, G., 1995. Late Quaternary surface circulation in the east equatorial Atlantic: Evidence from alkenone sea surface temperatures. Paleoceanography, 10:197-219.

Shackleton, N.J., Backman, J., Zimmerman, H., Kent, D.V., Hall, M.A., Roberts, D.G., Schnitker, D., Baldauf, J.G., Desprairies, A., Homrighausen, R., Huddlestun, P., Keene, J.B., Kaltenback, A.J., Krumsiek, K.A.O., Morton, A.C., Murray, J.W., and Westberg-Smith, J., 1984. Oxygen isotope calibration of the onset of ice-rafting and history of glaciation in the North Atlantic region. Nature, 307:620-623.

Shackleton, N.J., Hall, M.A., and Pate, D., 1995. Pliocene stable isotope stratigraphy of Site 846. In Pisias, N.G., Mayer, L.A., Janecek, T.R., Palmer-Julson, A., and van Andel, T.H. (Eds.), Proc. ODP, Sci. Results, 138: College Station, TX (Ocean Drilling Program), 337-355.

Sikes, E.L., Farrington, J.W., and Keigwin, L.D., 1991. Use of the alkenone unsaturation ratio Uk-37 to determine past sea surface temperatures: core-top SST calibrations and methodology considerations. Earth Planet. Sci. Lett., 104:36-47.

Sonzogni, C., Bard, E., Rostek, F., Dollfus, D., Rossell-Mele, A., and Eglinton, G., 1997. Temperature and salinity effects on alkenone ratios measured in surface sediments from the Indian Ocean. Quat. Res., 47:344355.

van der Smissen, J.H., and Rulkotter, J., 1996. Organofacies variations in sediments from the continental slope and rise of the New Jersey continental margin (Sites 903 and 905). In Mountain, G.S., Miller, K.G., Blum, P., Poag, C.W., and Twichell, D.C. (Eds.), Proc. ODP, Sci. Results, 150: College Station, TX (Ocean Drilling Program), 329-344.

Volkman, J.K., Barrett, S.M., Blackburn, S.I., and Sikes, E.L., 1995. Alkenones in Gephyrocapsa oceanica: implications for studies of paleoclimate. Geochim. Cosmochim. Acta, 59:513-520.

Volkman, J.K., Eglinton, G., Corner, E.D.S., and Sargent, J.R., 1980. Novel unsaturated straight-chain $\mathrm{C}_{37}-\mathrm{C}_{39}$ methyl and ethyl ketones in marine sediments and a coccolithophore Emiliania huxleyi. In Douglas, A.G., and Maxwell, J.R. (Eds.), Advances in Organic Geochemistry 1979: Oxford (Pergamon Press), 219-228.

Yamamoto, M., Ficken, K., Baas, M., Bosch, H.-J., and de Leuw, J.W., 1996. Molecular paleontology of the earliest Danian at Geulhemmerberg (the Nertherlands). Geol. Mijnbouw, 75:255-267.

Zhao, M., Rossell, A., and Eglinton, G., 1993. Comparison of two $\mathrm{U}^{\mathrm{k}}{ }_{37}$ sea surface temperature records for the last climatic cycle at ODP Site 658 from the sub-tropical Northeast Atlantic. Palaeogeogr., Palaeoecol., Palaeoclimatol., 103:57-65.

Date of initial receipt: 7 November 1996

Date of acceptance: 1 July 1997

Ms 159TSR-063 